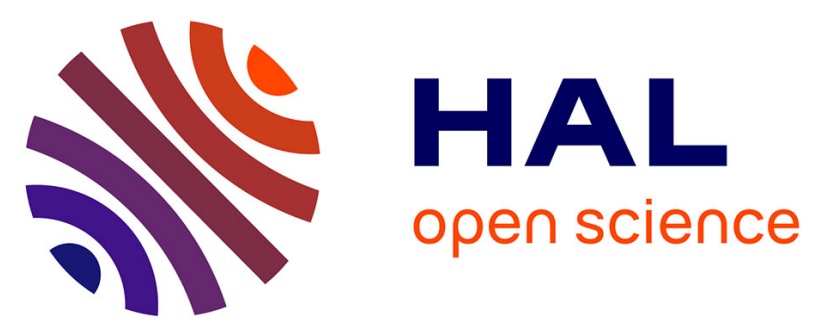

\title{
Morphodynamics of the exit of a cutoff meander: experimental findings from field and laboratory studies
}

J. Le Coz, M. Michalkova, A. Hauet, M. Comaj, Guillaume Dramais, K. Holubova, H. Piégay, André Paquier

\section{- To cite this version:}

J. Le Coz, M. Michalkova, A. Hauet, M. Comaj, Guillaume Dramais, et al.. Morphodynamics of the exit of a cutoff meander: experimental findings from field and laboratory studies. Earth Surface Processes and Landforms, 2010, 35 (3), pp.249-261. hal-01058300

\section{HAL Id: hal-01058300 https://hal.science/hal-01058300}

Submitted on 26 Aug 2014

HAL is a multi-disciplinary open access archive for the deposit and dissemination of scientific research documents, whether they are published or not. The documents may come from teaching and research institutions in France or abroad, or from public or private research centers.
L'archive ouverte pluridisciplinaire HAL, est destinée au dépôt et à la diffusion de documents scientifiques de niveau recherche, publiés ou non, émanant des établissements d'enseignement et de recherche français ou étrangers, des laboratoires publics ou privés. 
Coz, J. L., Michalková, M., Hauet, A., C $\square$ omaj, M., Dramais, G., Holubová, K., Piégay, H. and Paquier, A.

(2010), Morphodynamics of the exit of a cutoff meander: experimental findings from field and laboratory studies.

Earth Surface Processes and Landforms, 35: 249-261. doi: 10.1002/esp.1896

\section{Morphodynamics of the exit of a cut-off meander: experimental find- ings from field and laboratory studies}

Short title: Morphodynamics of the exit of a cut-off meander

J. Le Coz ${ }^{1}$, M. Michalková ${ }^{2}$, A. Hauet ${ }^{1}$, M. Čomaj ${ }^{3}$, G. Dramais ${ }^{1}$, K. Holubová ${ }^{3}$, H. Piégay ${ }^{2}$, A. Paquier ${ }^{1}$

Correspondence to J. Le Coz, e-mail: jerome.lecoz@cemagref.fr

1. Cemagref, 3 bis quai Chauveau CP 220, F-69336 Lyon Cedex 09 France

2. CNRS, UMR5600, Lyon, France

3. VUVH, Bratislava, Slovakia

\section{Abstract}

The morphological evolution of the entrances and exits of abandoned river channels governs their hydrological connectivity. The study focusses on flow and sediment dynamics in the exit of a cut-off meander where the downstream entrance is still connected to the main channel, but the upstream entrance is closed. Two similar field and laboratory cases were investigated using innovative velocimetry techniques (acoustic Doppler profiling, image analysis). Laboratory experiments were conducted with a mobile-bed physical model of the Morava river (Slovakia). Field measurements were performed in the exit of the Port-Galland cut-off meander, Ain river (France). Both cases yielded consistent and complementary results from which a generic scheme for flow patterns and morphological evolution was derived. A simple analogy with flows in rectangular side cavities was used to explain the recirculating flow patterns which developed in the exit. A decelerating inflow deposits bedload in the downstream part of the cavity, while the upstream part is eroded by an accelerating outflow, leading to the retreat of the upstream bank. In the field, strong secondary currents were observed, especially in the inflow, which may enhance the scouring of the downstream corner of the cavity. Also, fine sediment deposits constituted a silt layer in a transitional zone, located between the mouth of the abandoned channel and the oxbow-lake within the cut-off meander. Attempts at morphological prediction should consider not only the flow and sediment conditions in the cavity, but also the dynamics of the main channel. Keywords: river morphodynamics ; abandoned channel ; cut-off meander ; Morava river ; Ain river 


\section{Introduction}

Natural fluvial dynamics, as well as artificial training, sometimes lead rivers to abandon their main or secondary channels. The resulting perifluvial habitats usually show high ecological potential, depending on hydrological connectivity to the main channel flow (Amoros and Bornette, 2002). The hydrological connectivity of such ecosystems usually decreases in time due to fast and complex sedimentation processes occurring in the upstream entrance and downstream exit of the abandoned channels. In recent years, numerous restoration projects have attempted to reconnect the upstream and downstream ends of abandoned channels to the main flow to re-establish connectivity and enhance the quality of ecological habitat (Holubova et al., 1999; Simons et al., 2001; Baptist and Mosselman, 2002; Yokoyama et al., 2004). The morphodynamical behaviour of the entrance and exit of the abandoned channel plays an important role in the success of such reconnection measures. The monitoring of natural cutoffs from pre-cutoff stage can provide evidence on pattern and timescales of infilling and geomorphic adjustment (Hooke, 1995; Citterio and Piégay, 2008). However, the prediction of erosion/deposition patterns remains challenging because of the complexity of flow and sediment transport processes. In their study of oxbow-lakes of the Sacramento river, Constantine et al. (in press) showed that aggradation rates are faster within upstream entrances with high diversion angle because of enhanced bedload trapping.

The main goal of this study is to investigate the flow and erosion/deposition processes taking place in the exit of an abandoned meander where the exit is connected to the main channel, but the upstream entrance is closed. Such a situation is common for many former meanders during ordinary floods, as the inundation frequency is usually much higher at the exit than at the entrance. This kind of 'backflow' into the downstream end of the abandoned channel is a key-process for the infilling of oxbow-lakes (Shields and Abt, 1989).

Results from flume, field and numerical studies, cf. e.g. Langendoen et al. (1994); Kimura and Hosoda (1997); Muto et al. (2000); Uijttewaal et al. (2001); Nezu and Onitsuka (2002); Sukhodolov et al. (2004), provide the basis for a simplified scheme of the horizontal flow patterns in open-channel side cavities (Fig. 1). In roughly square cavities $(0.5<W / L<2$, with $W, L$, the width and length of the cavity, respectively), one recirculating gyre develops in the cavity. In more elongated cavities 
$(W / L<0.5$ or $W / L>2)$, a secondary gyre usually appears with a pattern of rotation in opposition to the main gyre. Although the downstream exits of abandoned channels are similar to side cavities, it is unknown whether flow patterns observed in rectangular cavities coincide with flow patterns that develop in the exits of abandoned channels, which may have complex geometrical configurations. In some groyne fields for instance, flow patterns were observed to deviate from the simplified scheme (Sukhodolov et al., 2002). Understanding flow patterns in exits is important because it determines patterns of erosion and deposition at these locations.

a) $0.5<$ W/L $<2$

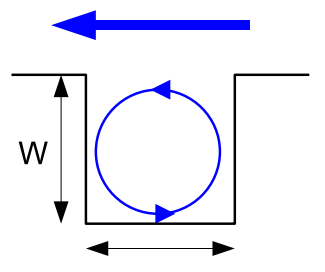

L b) $\mathrm{W} / \mathrm{L}<0.5$

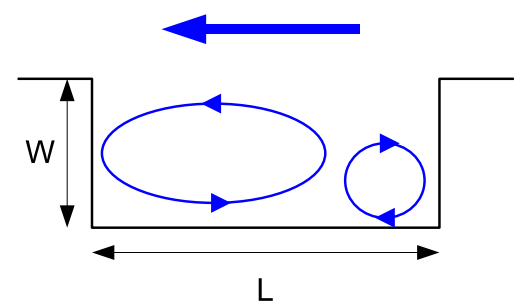

c) $W / L>2$

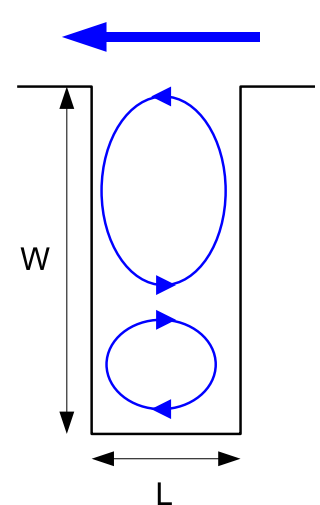

Figure 1: Recirculating flow patterns commonly observed in open-channel side cavities Modified from Sukhodolov et al. (2002)

In this study, both laboratory and field investigations were conducted to evaluate patterns of flow and erosion/deposition at the downstream exit of an abandoned meander bend. The first two sections of the paper outline the experimental methods used to obtain measurements in the laboratory (physical model of the Morava River, Slovakia) and in the field (Port-Galland meander, Ain river, France). In the next two sections, observed flow and erosion/deposition patterns in both cases are compared and analysed. A simple analogy with flows in rectangular cavities is proposed to explain the observations. Finally, a discussion is presented on the consistency of the hydro-sedimentary observations and on the effects of complex flow processes (3D, intermittent) on sediment transport in such cases. 


\section{Laboratory experiments}

\section{$2.1 \quad$ Experimental set-up}

Experiments were conducted on a $8.60 \mathrm{~m} \times 19 \mathrm{~m}$ physical model (Fig. 2a) built within the VUVH hydraulic facility (Bratislava, Slovakia). The model simulates a 2400m-long reach of the lower Morava river, which forms the boundary between Slovakia and Austria. This originally free-meandering tributary of the Danube was heavily regulated and channelized in the mid $\mathrm{XX}^{\text {th }}$ century. The physical model was used to study several reopening scenarios for two disconnected meanders, as part of a European Phare project entitled Morava-Dyje: Restoration of Fish Habitat and Hydrology (Holubova et al., 1999).

The main channel and the floodplain, including disconnected meanders, were reproduced from bathymetry surveys and aerial photographs. The floodplain (coarse sand) and the channel banks and substratum (concrete) were inerodible. In this study, the entrance of the main meander was closed. Observations were focused on the downstream exit, which was directly open to the main channel (Fig. 2b).

A constant flow rate was maintained upstream through an electromagnetic flowmeter. The water levels at six gauge points (cf. Fig. 2a) distributed along the channels were controlled with needle gauges. Upstream and downstream water levels were stabilized in stilling basins. The water surface profile in the flume was calibrated at each gauge point within 4-5 $\mathrm{mm}$ (i.e. $15-20 \mathrm{~cm}$ at real river scale) from the in-situ measured water surface profile.

Spatial horizontal and vertical scale factors were $\lambda_{L}=160$ and $\lambda_{h}=40$ respectively. The corresponding distorsion factor, $\Delta=\lambda_{L} / \lambda_{h}=4$, yields water depths large enough to minimize capillary effects. Throughout the paper, $\lambda_{x}$ represents $X / x$, where $X$ is a given real quantity and $x$ is the corresponding quantity in the physical model. The slope of the main channel of the flume was $J=0.585 \%$, which corresponds to $0.15 \%$ o at real river scale $\left(\lambda_{J}=1 / \Delta=0.25\right)$. The main hydrodynamical and sedimentological scale factors were computed according to classical Froude and Shields similarity rules. In particular, the time scale factors for hydrodynamical and sedimentological processes were $\lambda_{t}=25.5$ and $\lambda_{t_{s}}=400$, respectively.

A typical sketch of the river and meander cross-sections is shown in Fig. 2c. The river and me- 

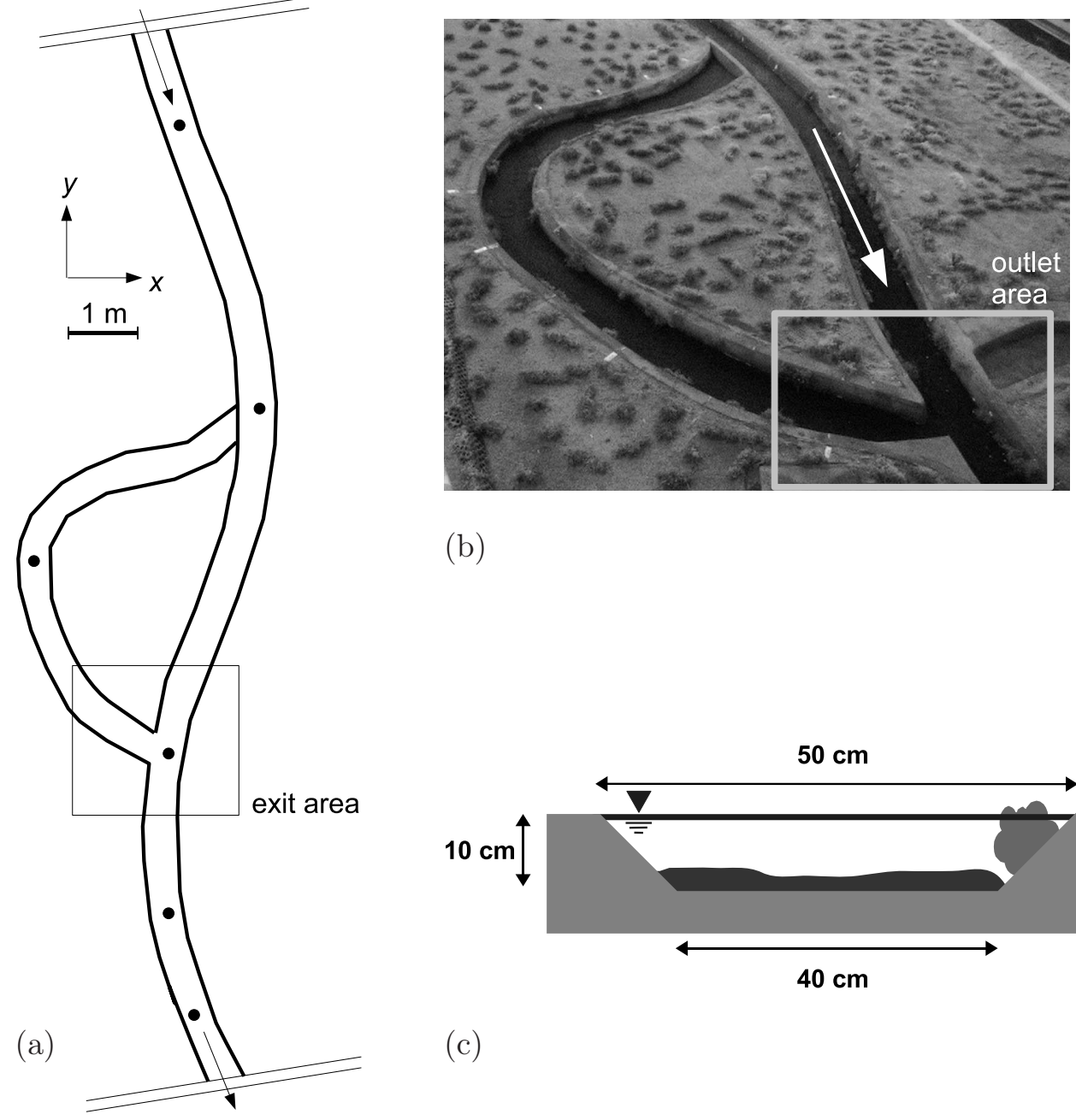

(b)

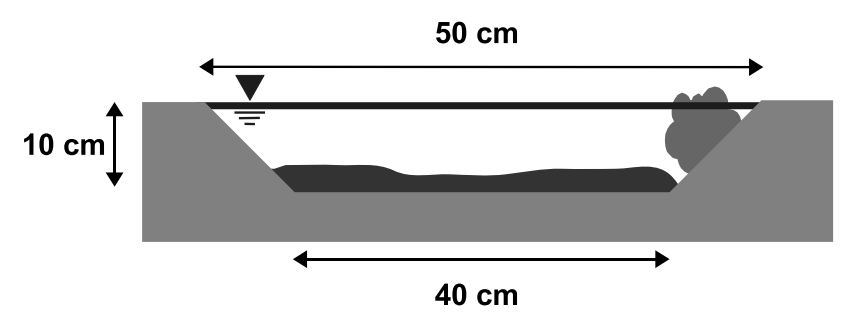

(c)

Figure 2: (a) Sketch of the physical model with the six gauge points and the area of interest (exit area); (b) Oblique view of the study meander (looking upstream); (c) Typical cross-section in the physical model, with mobile coal particle layer and paper bush fixed in the bank 
ander beds were covered with a mobile layer of monodisperse coal particles with a median diameter $d_{50}=1.07 \mathrm{~mm}\left(\lambda_{d_{50}}=5\right)$ and a sorting coefficient $\sqrt{d_{84} / d_{16}}=1.5$. The sediment density was $\rho_{s}=1330 \mathrm{~kg} / \mathrm{m}^{3}\left(\lambda_{\rho_{s}}=2.0\right)$. The bank roughness was enhanced by small bushes made of paper held in place by iron wire meshes.

\subsection{Morphodynamical simulations}

For two different simulation runs, contrasting shapes were given to the downstream corner of the exit (see Fig. 3). Run 1 was conducted with a smooth corner (flow incidence angle roughly $60^{\circ}$ ), whereas run 2 was conducted with a sharp corner and a reduced mouth (flow incidence angle roughly $\left.90^{\circ}\right)$.

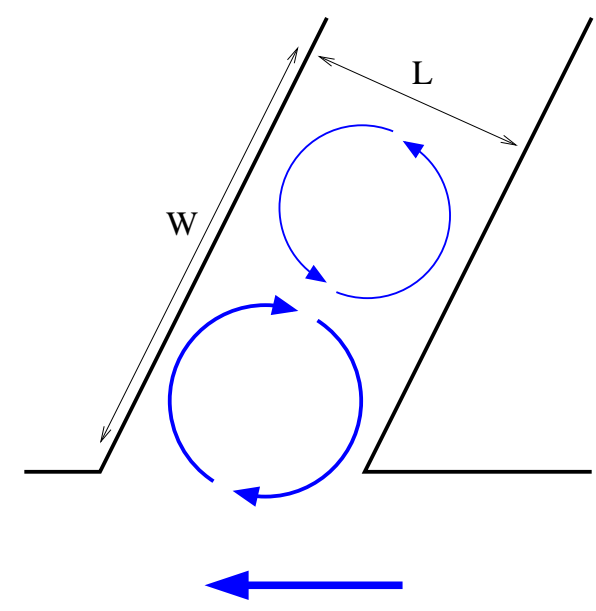

(a)

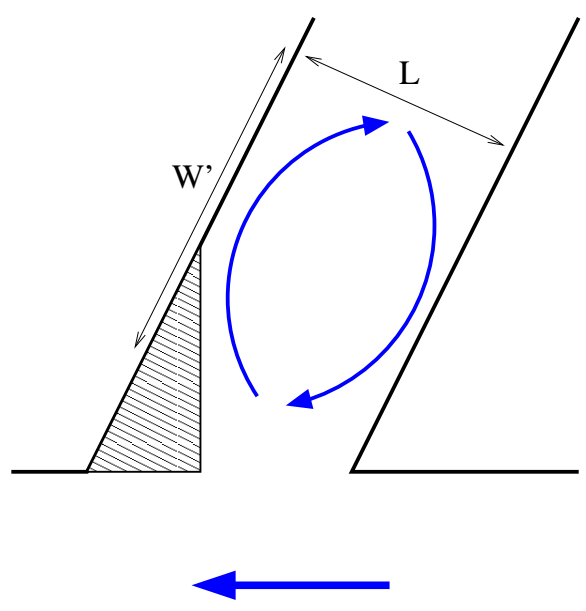

(b)

Figure 3: Simplified shape of the Morava cavity for run 1 (a, smooth corner) and run 2 (b, sharp corner) and an analogy with flows in rectangular side cavities to explain the observed flow patterns (see Section 4.1).

Each experimental run was performed with the bankfull discharge rate $(6.4 \mathrm{l} / \mathrm{s}$, representing $260 \mathrm{~m}^{3} / \mathrm{s}$ at real scale). During each run, 1D vertical velocity profiles were acquired throughout two cross-sections located upstream and downstream the area of interest, with 5 positions in each section. A MET-FLOW Ultrasonic Velocity Profile Monitor (UVP), typically suitable for velocities as low as $1 \mathrm{~cm} / \mathrm{s}$, was used. The flow rates computed according to a classical velocity-area method fell within $2-3 \%$ of the nominal discharge maintained upstream. 
Initially the mobile bed was manually smoothed according to a uniform $0.585 \%$ streamwise slope in the main channel and a zero slope in the cut-off meander. Two hours were required to achieve the nominal discharge, water level calibration and hydro-sedimentary equilibrium in the main channel. At this point, alternate bars formed and the bedload transport rate and morphological changes reached equilibrium. As the upstream sediment input was zero, the achievement of hydrosedimentary equilibrium induced a sediment deficit in the most upstream part of the main channel. During each run, degraded reach about 1-m long developed at the upstream end of the main channel. However, this deficit area remained far upstream from the meander exit.

At the end of each run, the physical model was gradually emptied. The bathymetry of the area of interest (cf. Fig. 2a) was then surveyed every 2-10 cm streamwise and 1-2 cm spanwise with a laser distance sensor mounted on a bridge crane.

\subsection{Image-based flow measurements (LS-PIV)}

The single-beam UVP measures $1 \mathrm{D}$ velocity components only. To provide a $2 \mathrm{D}$ characterization of the flow, a Large-Scale Particle-Image-Velocimetry (LS-PIV) technique was used to measure the complex surface velocity patterns in the meander exit. The principle of operation of LS-PIV consists of estimating the most likely displacement of clusters of gray-scale pixels between two successive images using correlation techniques (Hauet et al., 2008). Through accurate geometric rectification of the images (Fujita et al., 1998), the instantaneous and time-averaged flow fields at the free-surface can be computed.

During both experimental runs, video sequences were recorded with an ordinary digital mini-DV camescope (CAnonMv750i, 25 frames per second, $720 \times 576$ pixels resolution). The flow freesurface was manually seeded with floating paper confetti (diameter $\sim 1 \mathrm{~cm}$ ). As the tilt angle of the camera was close to $90^{\circ}$, the magnitude of geometric corrections was quite limited. The correction matrices for geometric rectification were computed using a regular $5 \mathrm{~cm} \times 5 \mathrm{~cm}$ grid visible at the beginning and at the end of each sequence (Fig. 4). The LS-PIV analysis was similarly performed on a $5 \mathrm{~cm} \times 5 \mathrm{~cm}$ computational grid.

The time step between successive images was set to obtain apparent tracer displacements of 


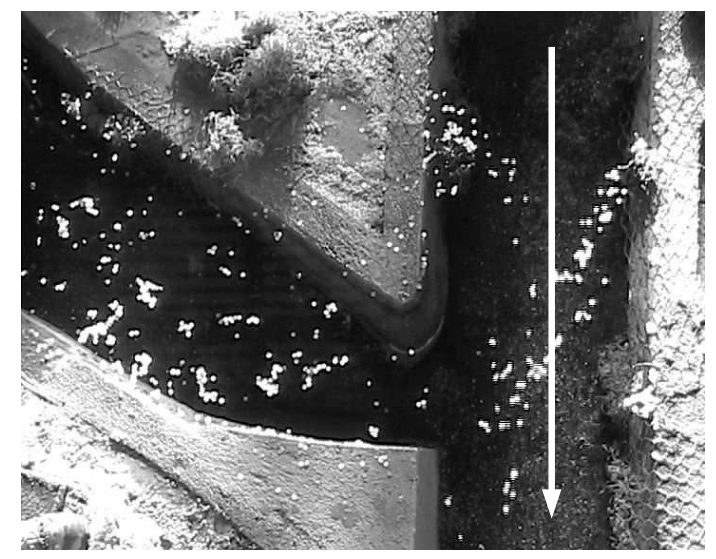

(a)

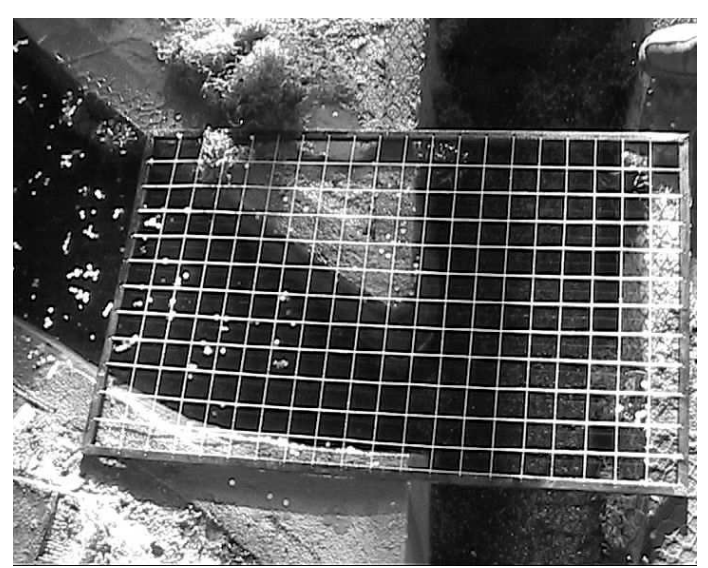

(b)

Figure 4: Example of LS-PIV images during run 2. Confetti-seeded flow (a) and rectification grid (b)

approximately 15 pixels between images. The resulting rate was 10 images per second in the exit. For each instantaneous flow field, erroneous vectors were filtered out based on reasonable displacement and correlation coefficient restrictions. The processed movie sequences lasted from $30 \mathrm{~s}$ to a few minutes to properly average the surface flow field.

\section{$3 \quad$ Field campaigns}

\subsection{Study site}

The lower Ain river, South-Eastern France, is a gravel-bed river with an average slope of $0.15 \%$ and mean annual discharge of $124 \mathrm{~m}^{3} / \mathrm{s}$ (www.rdbrmc.com/hydroreel2/). During the first half of the twentieth century, the river channel pattern changed from braided to a freely-meandering style. Though regulated by dams since the sixties, the fluvial dynamics continue to be active yielding a variety of abandoned channels. Along the Port-Galland study reach, the active channel bed showed a mean degradation rate of only $0.8 \mathrm{~cm}$ between 1986 and 1999 (Rollet et al., 2005).Bed materials consist of gravel with $d_{50}=1.5 \mathrm{~cm}, d_{90}=6 \mathrm{~cm}$, and sorting coefficient $\sqrt{d_{84} / d_{16}}=2.9$ (Rollet, 2007). Gravels in the Ain river consist of jurassic limestone with a density of $2600-2700 \mathrm{~kg} / \mathrm{m}^{3}$.

The Port-Galland abandoned channel was previously a meander of the Ain river. This reach was artificially cut-off in 1964 to protect a newly-built bridge (Fig. 5a). As can also be seen in 


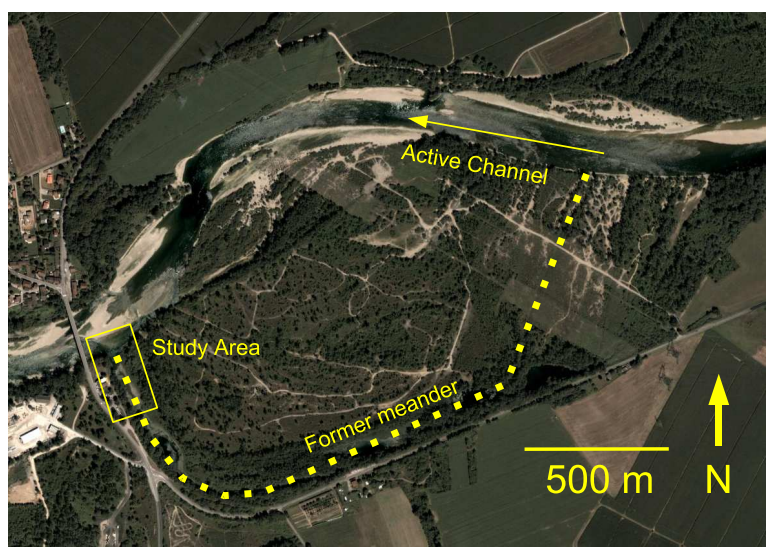

(a)

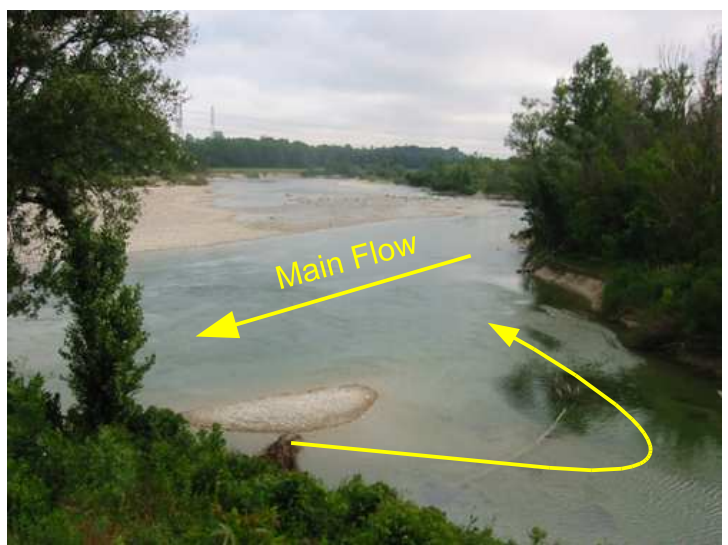

(b)

Figure 5: The Port-Galland study site: (a) recent aerial view of the active and abandoned channels (Google Earth); (b) low-flow view of the downstream exit of the former meander

Fig. 5, the new river channel curves in the opposite direction of the abandoned channel. This study site was chosen because its exit presented several advantages for hydrodynamical investigation: frequent connection to the river flow, easy access by car, overhanging embankment, wide and slightly vegetalized former channel. Additionally, a well-rated gauging station operated by the Compagnie Nationale du Rhône (CNR) is located a few metres from the bridge.

From morphological surveys, Rollet et al. (2005) estimated the mean sedimentation rate to be $1.4 \mathrm{~cm} / \mathrm{yr}$ in oxbow-lakes within the abandoned channel and $0.5 \mathrm{~cm} / \mathrm{yr}$ in the downstream exit. Upstream connection of the Port-Galland abandoned channel occurs for discharges greater than $1000 \mathrm{~m}^{3} / \mathrm{s}$, which corresponds to a 2.5 year return period (www.rdbrmc.com/hydroreel2/). In contrast, downstream hydrological connection is almost continuous (about 300 days per year). Upstream connection is likely to induce severe changes in the morphology of the exit of the cutoff meander, because the flow patterns are expected to differ dramatically from those observed for downstream connection only. The corresponding morphodynamical processes are beyond the scope of this study. However, they should be taken into account when considering the long-term adjustment of cut-off meanders.

The abandoned river channel forms side cavity at the downstream junction with the active channel (Fig. 5b). The downstream side of the cavity, normal to the main flow direction, is protected 
by an inerodible dyke that previously supported the road to the former bridge. The upstream side of the cavity is more complex and shows active bank erosion. A noticeable gravel deposit surrounded by deeper areas is located in the cavity near the downstream corner. A sand bar separates the mouth of the abandoned channel from the first of a series of oxbow-lakes the beds of which is covered by fine material (sand and silt). Due to almost permanent connection to the river, the deposits in the Port-Galland cavity are not vegetated yet.

\subsection{Morphological surveys}

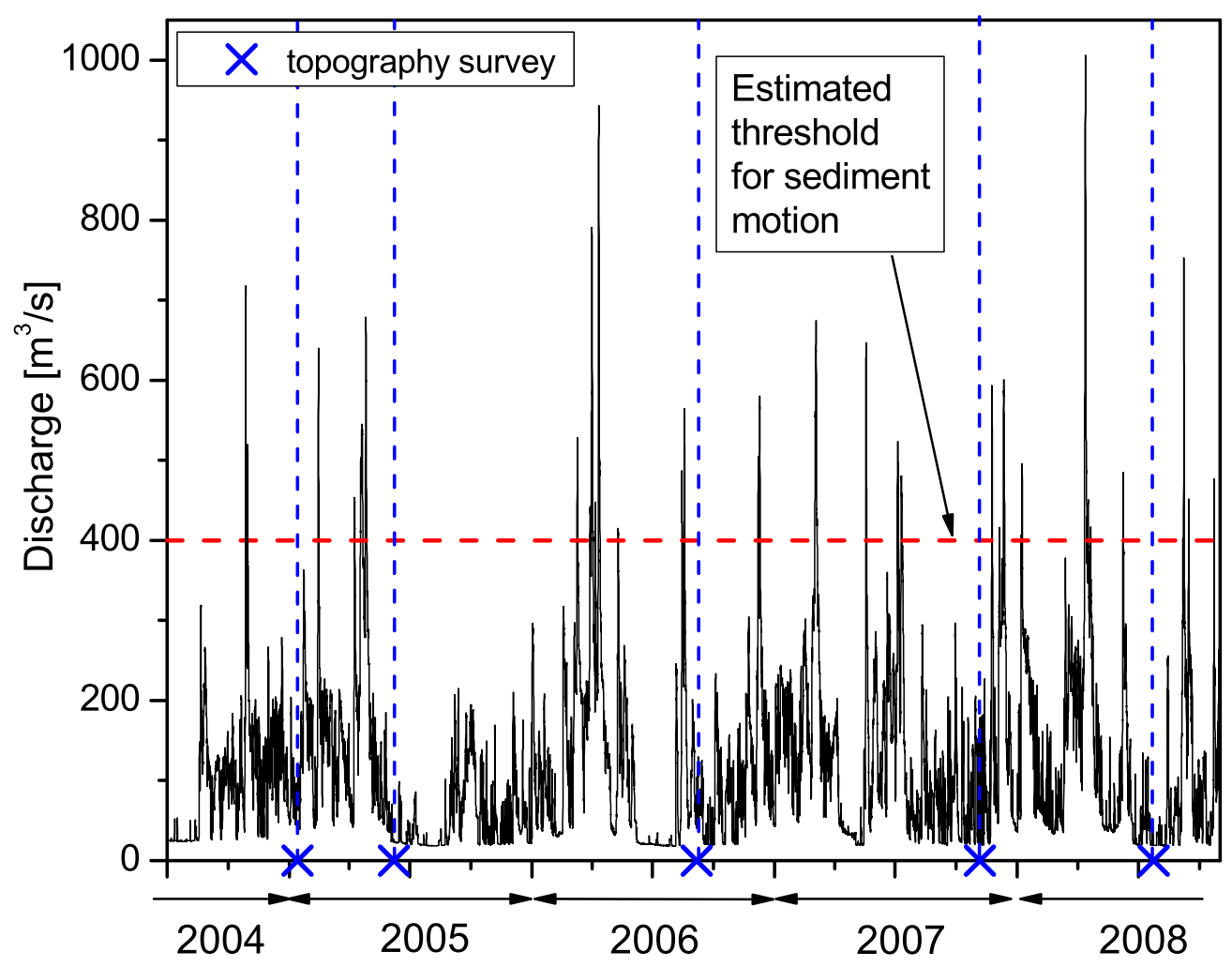

Figure 6: Discharges at Port-Galland gauging station (CNR) over 2005-2008

The morphological evolution of the exit of the Port-Galland cut-off meander was monitored from 2005 to 2008 (Fig. 6). Hereafter, the 5 topography campaigns performed on 2005/01/13, 2005/06/07, 2006/09/06, 2007/11/06, 2008/07/24, are referred to as topography campaigns 2005a, 2005b, 2006, 2007, 2008, respectively. Following the observations by Rollet (2007), the discharge threshold above which active bedload transport occurs in the main channel under consideration was 
estimated to equal $400 \mathrm{~m}^{3} / \mathrm{s}$. Periods between two consecutive topography campaigns involved 8 to 11 days with discharge exceeding $400 \mathrm{~m}^{3} / \mathrm{s}$.

The geometry of the exit was measured using either an optical total station (Leica TC305) or differential GPS (Leica GPS 1200 RTK), with a set of fixed reference points. The accuracy of horizontal and vertical measurements was on the order of centimeters. Additionally, during campaigns $2005 \mathrm{~b}$ to 2008 , the thickness of the fine sediment layer (sand and silt) above the primary gravel bed of the abandoned channel was probed at numerous locations with a metal rod.

Despite differences in the distribution of measurement points among surveys, all of them were dense enough to allow spatial interpolation and comparisons. Typically, the geometry was surveyed every $5 \mathrm{~m}$ streamwise and 1-2 $\mathrm{m}$ spanwise. As noticeable exceptions, the upstream corner of the exit was not surveyed during campaigns $2005 \mathrm{~b}$ and 2007 . The bed geometry and the fine sediment layer were interpolated by linear triangulation on a regular grid with $1 \mathrm{~m}$ resolution. Differences between consecutive topographic grids facilitated quantification of morphological evolution.

\subsection{ADcp campaigns}

Moving-vessel aDcp measurements were performed to obtain mean velocity data on transects across the exit of the cut-off meander. The aDcp was a Teledyne RDI ${ }^{\circledR}$ WorkHorse RioGrande operating at $1200 \mathrm{kHz}$. The water velocity data were acquired with BroadBand modes 1 and 12 . In all cases, the bin size was set to $30 \mathrm{~cm}$ and the sampling rate was nearly $1 \mathrm{~Hz}$.

During each campaign, several (6 to 10) replicate crossings along each transect were achieved by mounting the aDcp on a small non-powered boat equipped with a surveying prism and regularly measuring the location of the aDcp from the bank using a total station (Leica ${ }^{\circledR}$ TC305). Each aDcp survey lasted between 1 and 2 hours. The main limitation was navigational safety: velocity bursts and floating debris were a constant concern and it was often impossible to get data in the vicinity of the main river flow.

Specific post-processing tools were implemented to position and average aDcp data (flow depth and 3D velocity field) acquired on replicate crossings. A description of the principle and validation of these post-processing tools can be found in Le Coz et al. (2008). Using this procedure, the 
bathymetry profiles and mean 3D velocity fields were established for all the transects of the 10 aDcp campaigns.

Though the river discharge was regulated by a series of dams, flow conditions were not controlled specifically for our observations. Ten aDcp measurement campaigns took place during 7 hydrological events (A to G) in 2005 and 2006 (Fig. 7). The full range of downstream connecting flow rates was investigated, from low flow $\left(200 \mathrm{~m}^{3} / \mathrm{s}\right.$ ) to values close to the upstream connecting flow (above $1000 \mathrm{~m}^{3} / \mathrm{s}$ ). Relevant hydraulic parameters during each aDcp campaign are reported in Tab. 1 .

Apart from event B, which had stationary low flow conditions, the flood events lasted between 1 and 2 days. For each event, three periods can be distinguished: a rising limb, a plateau and a falling limb. Campaign aDcp-2 was the only survey with longstanding stationary conditions, while campaigns aDcp-6 and aDcp-9 were performed after the 10 h-long plateau periods of floods E and G respectively. Campaigns aDcp-3/4/7/8 were performed in the middle or at the end of the rising limbs of floods $\mathrm{C} / \mathrm{D} / \mathrm{F} / \mathrm{G}$ respectively. Campaigns aDcp-1/5/10 were performed during the falling limbs of floods A/D/G respectively.
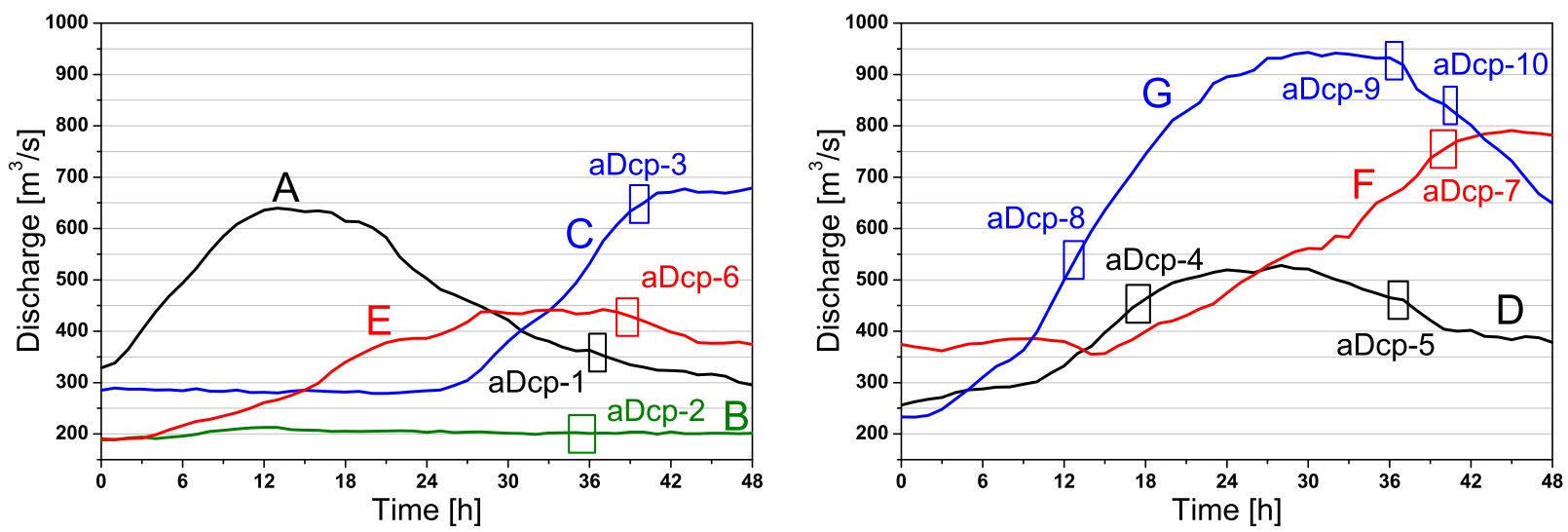

Figure 7: Hydraulic conditions in the main river channel during aDcp campaigns (aDcp-1 to aDcp-10) and flood events A to G, from the hourly discharges measured at Port-Galland gauging station (CNR). 


\begin{tabular}{|c|c|c|c|c|c|c|c|c|}
\hline campaign & flood & date & time & $\begin{array}{c}\text { discharge } Q \\
{\left[\mathrm{~m}^{3} / \mathrm{s}\right]}\end{array}$ & $\begin{array}{c}\text { water level } \\
\text { [m NGF] }\end{array}$ & $\begin{array}{c}U \\
{[\mathrm{~m} / \mathrm{s}]}\end{array}$ & $\begin{array}{l}F r \\
{[-]}\end{array}$ & $\begin{array}{l}R e \\
{[-]}\end{array}$ \\
\hline aDcp-1 & $\mathrm{A}$ & $2005 / 02 / 14$ & $12: 00-13: 00$ & 360 & 191.79 & 1.66 & 0.39 & $3.1 \times 10^{6}$ \\
\hline aDcp-2 & B & $2005 / 03 / 04$ & $10: 30-12: 30$ & 200 & 191.23 & 1.24 & 0.28 & $2.5 \times 10^{6}$ \\
\hline aDcp-3 & $\mathrm{C}$ & $2005 / 04 / 25$ & $15: 00-16: 30$ & 650 & 192.57 & 2.03 & 0.44 & $4.5 \times 10^{6}$ \\
\hline aDcp-4 & $\mathrm{D}$ & $2006 / 03 / 09$ & $16: 30-18: 30$ & 450 & 192.07 & 1.79 & 0.42 & $3.3 \times 10^{6}$ \\
\hline aDcp-5 & $\mathrm{D}$ & $2006 / 03 / 10$ & $12: 00-13: 30$ & 460 & 192.08 & 1.79 & 0.42 & $3.3 \times 10^{6}$ \\
\hline aDcp-6 & $\mathrm{E}$ & $2006 / 03 / 29$ & $13: 45-15: 30$ & 430 & 192.01 & 1.78 & 0.42 & $3.2 \times 10^{6}$ \\
\hline aDcp-7 & $\mathrm{F}$ & $2006 / 03 / 31$ & $15: 15-17: 00$ & 750 & 192.83 & 2.09 & 0.43 & $5.1 \times 10^{6}$ \\
\hline aDcp-8 & G & $2006 / 04 / 10$ & $12: 00-13: 30$ & 540 & 192.29 & 1.92 & 0.44 & $3.8 \times 10^{6}$ \\
\hline aDcp-9 & G & $2006 / 04 / 11$ & $11: 45-13: 00$ & 925 & 193.22 & 2.22 & 0.43 & $6.1 \times 10^{6}$ \\
\hline aDcp-10 & G & $2006 / 04 / 11$ & $16: 00-17: 00$ & 830 & 193.01 & 2.15 & 0.43 & $5.5 \times 10^{6}$ \\
\hline
\end{tabular}

Table 1: Hydraulic conditions in the main river channel during aDcp campaigns. The flow rate $Q\left[\mathrm{~m}^{3} / \mathrm{s}\right]$ and the water level above sea level (NGF reference system) were measured at PortGalland gauging station (CNR). $U[\mathrm{~m} / \mathrm{s}]$ is the bulk velocity, $Q / S(h)$, with $S\left[\mathrm{~m}^{2}\right]$ the cross-section area computed from the bathymetry at the gauging station. The Froude and Reynolds numbers were computed as $F r=U / \sqrt{g D_{h}}$ and $R e=U R_{h} / \nu$, respectively, with $g=9.81 \mathrm{~m} / \mathrm{s}^{2}$ the gravity acceleration, $D_{h}[\mathrm{~m}]$ the hydraulic depth, $R_{h}[\mathrm{~m}]$ the hydraulic radius, and $\nu=10^{-6} \mathrm{~m}^{2} / \mathrm{s}$ the kinematic viscosity of water. 


\section{Results: Observed Flow Structure}

\subsection{Laboratory case: Surface flow patterns}

The time-averaged surface flow patterns measured by LS-PIV in the exit of the meander in the physical model varied significantly with shape of the channel mouth. During run 1 (smooth corner, Fig. 8a), a 2-gyre system developed, as observed in spanwise elongated open-channel side cavities (Fig. 1). The gyre at the mouth of the channel had a mean surface velocity magnitude that was roughly $3 \mathrm{~cm} / \mathrm{s}$ in the inflow and less than $2 \mathrm{~cm} / \mathrm{s}$ in the outflow. The secondary contra-rotating gyre was twice as large as the primary one with velocity magnitudes as low as a few $\mathrm{mm} / \mathrm{s}$. During run 2 (sharp corner, Fig. 8b), a 1-gyre system recirculated over the whole space occupied by the 2-gyre system of run 1 . The velocities measured near the downstream corner suggested a highly 3D flow structure, confirmed by visual observation of liquid particles traced by dye injection.

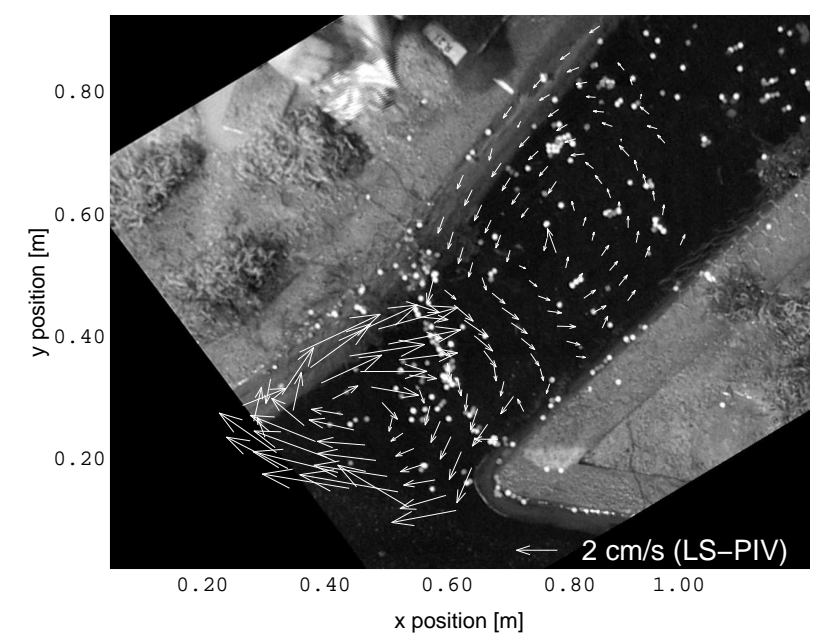

(a)

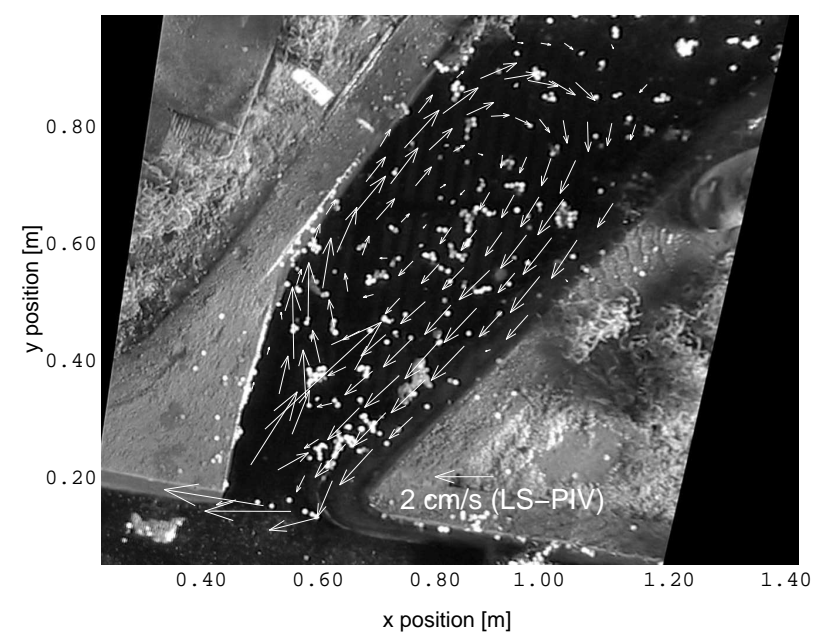

(b)

Figure 8: Time-averaged surface velocity fields yielded by LS-PIV: run 1, smooth corner (a) and run 2, sharp corner (b). The main channel is located at the bottom of each picture, with main flow from right to left.

Such a change in flow patterns can be interpreted according to the conceptual model for rectangular open-channel side cavities (cf. Fig 1). In run 1 (see Fig. 3a), the width of the cavity can be equated to the distance along the downstream side of the cavity from the mouth to the end of the 
secondary gyre $(W \sim 90 \mathrm{~cm})$. In run 2 (see Fig. 3b), the modified corner apparently reduces the effective width to $W^{\prime} \sim 60 \mathrm{~cm}$, the length of the single gyre that forms inward of the contracted mouth of the cavity. In both cases, the length of the cavity may be approximated by the width of the secondary channel, i.e., $L \sim 40 \mathrm{~cm}$. This method of estimating aspect ratios $(W / L=2.25$ for run 1 and $W^{\prime} / L=1.5$ for run 2) of the cavity yields results consistent with the conceptual model (Fig. 1 and Fig. 3). However, in both cases it would have been difficult to predict the effective width of the cavity from geometric considerations only.

\subsection{Field case: Depth-averaged flow patterns}

The interpolated velocity fields from aDcp-1 to aDcp-10 campaigns support a 3-class typology of the depth-averaged flow patterns developing in the exit of the Port-Galland cut-off meander during floods. As an illustration of the 3 flow regimes, Fig. 9 (top row) presents the mean velocities from aDcp-2, aDcp-6, aDcp-7 campaigns, superimposed with the same reference bed elevation map. The three flow regimes represented in Fig. 9 (bottom row) appear to depend on the river discharge only, and not on the flood hydrograph (steady / rising / falling). Regime R1, illustrated by the aDcp-2 (steady phase) campaign, corresponds to low flow conditions $\left(Q<300 \mathrm{~m}^{3} / \mathrm{s}\right)$. Regime R2, illustrated by the aDcp-6 (steady phase) campaign, corresponds to mid flow conditions $\left(300<Q<500 \mathrm{~m}^{3} / \mathrm{s}\right.$ ). Regime R3, illustrated by the aDcp-7 (rising phase) campaign, corresponds to high flow conditions $\left(Q>500 \mathrm{~m}^{3} / \mathrm{s}\right)$.

In all three flow regimes, the mean flow patterns were organized around a main gyre arising from the diversion of the main river flow by the downstream corner of the side cavity. For each flow regime, the inflow and outflow limbs of the main gyre as well as secondary gyres are depicted and interpreted in light of the conceptual model presented in Fig. 1.

Regime R1 is a one-gyre flow pattern characterized by velocity vectors that change from an orientation into the abandoned channel at one end of the aDcp transects to an orientation toward the main channel at the other end of the transects. As expected from the conceptual model (Fig. 1b), a secondary gyre also develops near the upstream corner of the cavity. Gyre 2 occupied a small area and rotated intermittently. As a consequence, it was more evident in data for single transects 

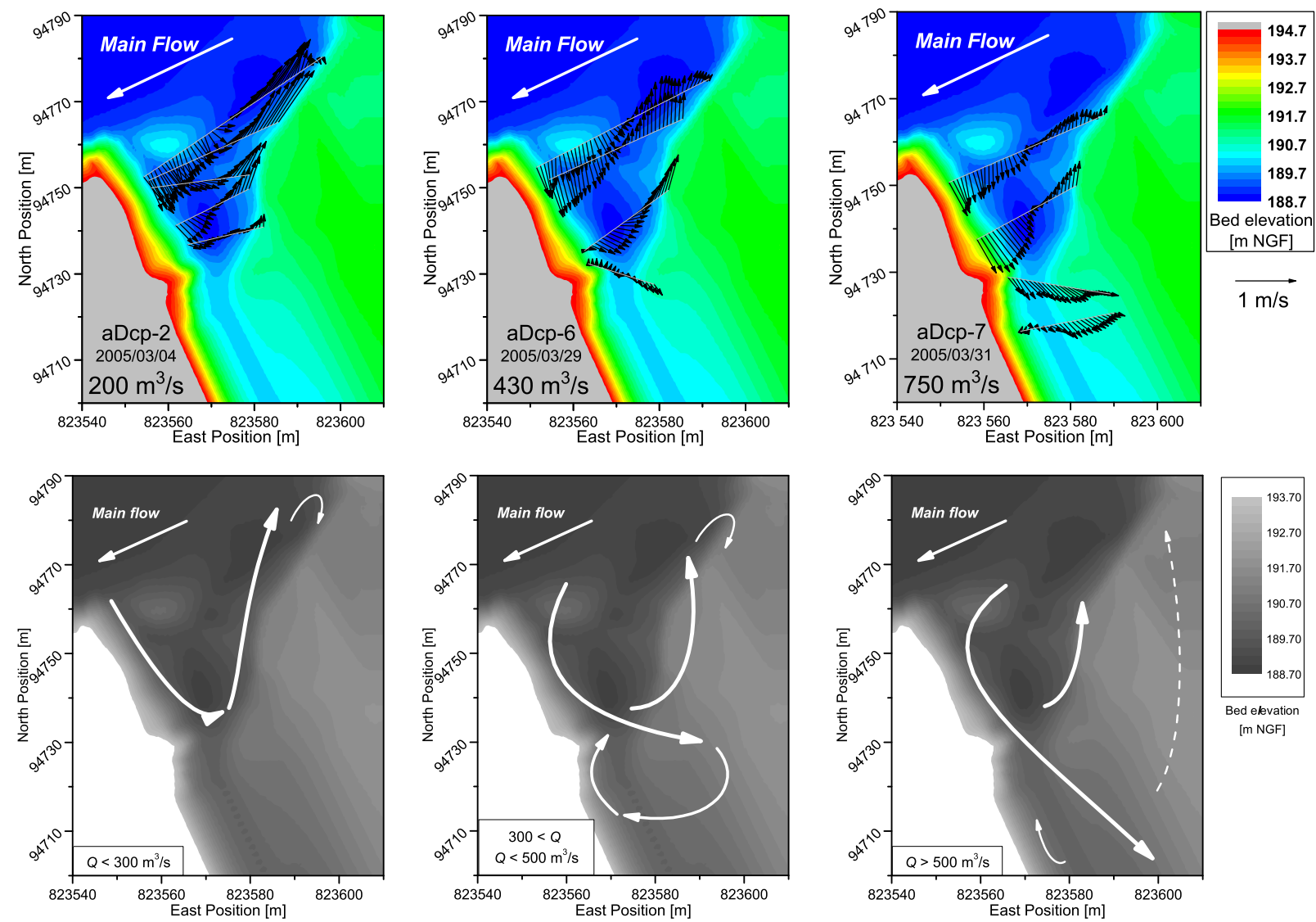

Figure 9: Flow regimes R1, R2, R3 developing in the side cavity according to river discharge level: low flow conditions $\left(Q<300 \mathrm{~m}^{3} / \mathrm{s}\right)$, mid flow conditions $\left(300<Q<500 \mathrm{~m}^{3} / \mathrm{s}\right)$, and high flow conditions $\left(Q>500 \mathrm{~m}^{3} / \mathrm{s}\right)$. Each flow regime is illustrated by the horizontal flow patterns measured by aDcp (top row) and the corresponding conceptual model (bottom row).

than it was in the averaged data presented here.

Regime R2 is more complicated since velocity magnitudes were greater and a part of the inflow was diverted towards inner parts of the cavity. Data from aDcp- 1 and aDcp- 6 campaigns indicate that flow impingement against the embankment was stronger than for Regime R1. Some parts of the right bank were barely inundated at this stage and the shallow outflow in this part of the meander exit was missed by the aDcp survey. The secondary gyre observed in Regime R1 remained evident by the pattern of some scattered vectors near the upstream corner of the cavity. As the inflow extended toward the inner side of the cavity (sand deposit), it activated a third gyre with 
weak opposing circulation in accordance with the conceptual model (Fig. 1-c).

Regime R3 is an amplification of Regime R2 flow patterns because of an increase in river velocities and momentum transfer to the cavity. The incident flow expanded in a large area of the cavity above the gravel deposit. The resulting inflow was powerful, straight and deep as shown by the large velocities measured on the inner transects. Due to safety concerns, data were difficult to acquire near the river, so gyre 2 was difficult to measure. Visual observations suggested that it was still present but in competition with a wide and slow outflow covering large vegetated areas on the right bank of the cavity. Gyre 3 manifested itself as low reverse velocities on the left side of the inner transect.

Like the laboratory case, the field case can be interpreted in relation with the flow patterns expected to develop in rectangular open-channel side cavities (cf. Fig 1). As river discharge varied, different parts of the cavity were submerged and hydrodynamically activated. Three elementary recirculating systems $\mathrm{S} 1, \mathrm{~S} 2$, and $\mathrm{S} 3$ can be defined (Fig 10). The dimensions of the corresponding rectangular cavities may be roughly estimated as follows: $L_{1} \sim L_{3} \sim 65 \mathrm{~m}, L_{2} \sim W_{1} \sim 40 \mathrm{~m}$, $W_{2} \sim W_{3} \sim 80 \mathrm{~m}$. The resulting aspect ratios $\left(W_{1} / L_{1} \sim 0.6, W_{2} / L_{2} \sim 2.0, W_{3} / L_{3} \sim 1.2\right.$, for recirculating systems S1, S2, S3, respectively) yield the flow patterns depicted in Fig 10. Observed flow regimes R1, R2, R3, can be explained as the superposition of recirculating systems $\mathrm{S} 1, \mathrm{~S} 1+\mathrm{S} 2$, $\mathrm{S} 2+\mathrm{S} 3$, respectively.

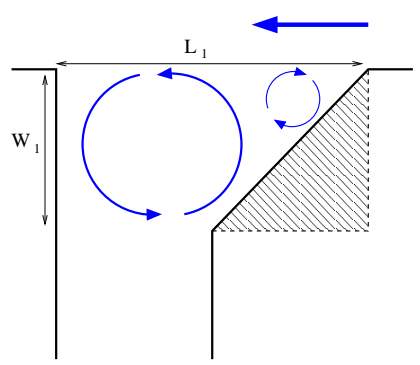

S1

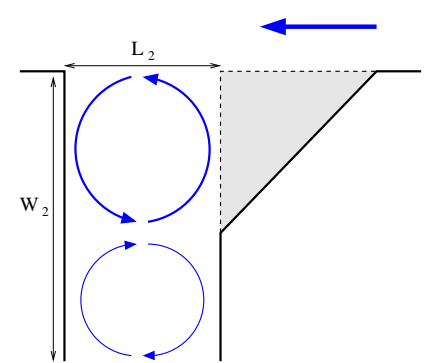

S2

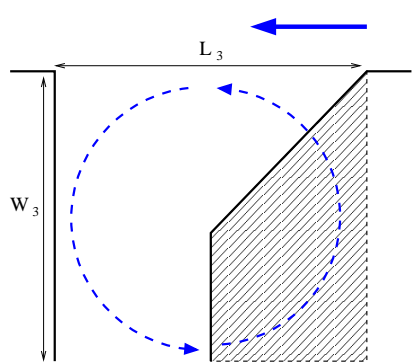

S3

Figure 10: A simple analogy with flows in rectangular side cavities to explain the flow patterns observed in the Port-Galland cavity. Observed flow regimes R1, R2, R3, can be seen as the superposition of recirculating systems S1, S1+S2, S2+S3, respectively. Shaded areas must be included (hatching) or excluded (gray) for defining the considered rectangles. 


\section{Results: Morphodynamics}

\subsection{Laboratory case: Observed erosion/deposition patterns}

In the laboratory case, the final bed topography surveys for both experimental runs yielded similar erosion/deposition spatial patterns in the meander exit and in the main channel (Fig. 11). Some elongated deposits developed in the vicinity of the downstream side of the exit. Likely because of 3D plunging currents, the downstream deposit was separated from the bank of the downstream corner. In run 1, this effect was less visible because 3D currents were not as strong because of the smoother shape of the downstream corner. Visual observation indicated an intermittent movement of particles inward.
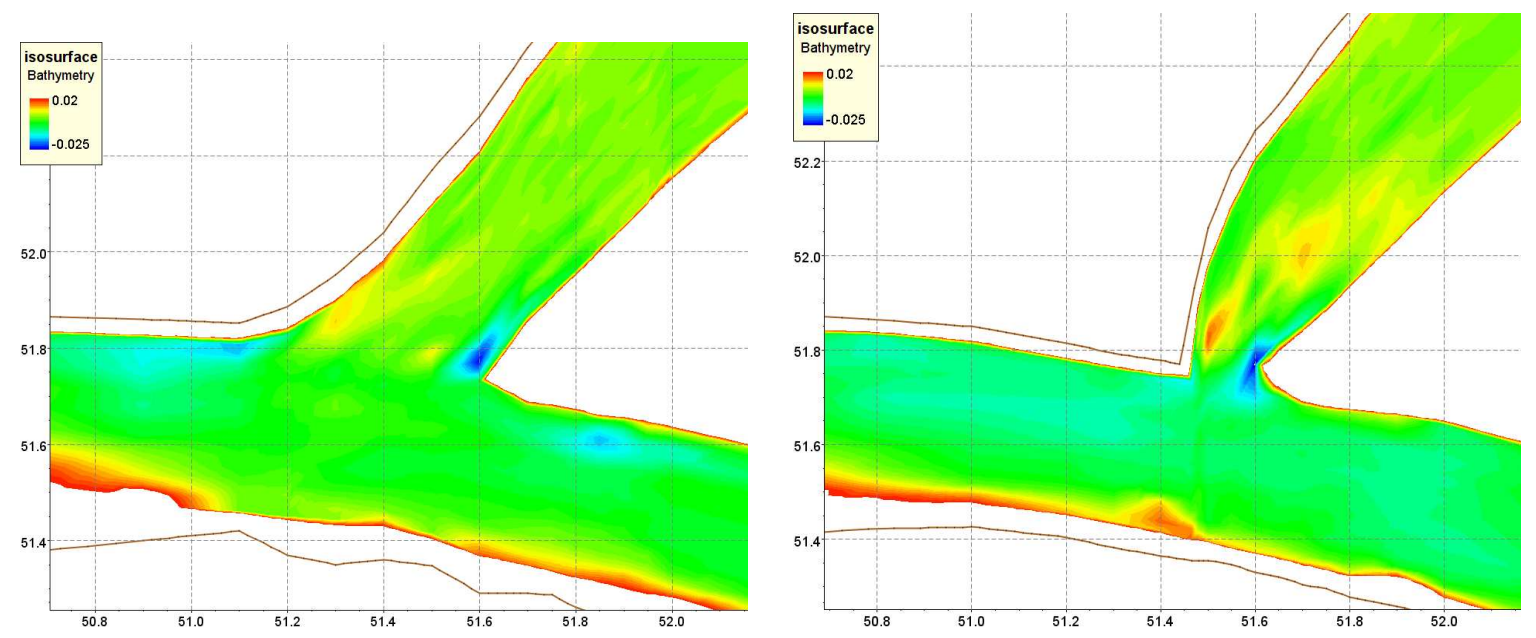

Figure 11: Deposition and erosion areas from the measured final bed topography (run 1 top, run 2 bottom, all dimensions in meters).

In contrast, a marked scour of the bank toe near the upstream corner was observed in both cases. This effect was possibly enhanced by the presence of a steep inerodible concrete bank. Had the experimental bank been erodible, bank retreat probably would have been observed.

In addition, a general degradation of the main channel was observed for both runs, especially on the right side (near the mouth of the side channel). Such incision might be related to sediment trapping in the cavity. Also, deposition on the left side of the main channel across from the exit was probably caused by friction associated with the paper bushes on the banks and by the development 
of an alternate bar immediately downstream.

Whereas erosion/deposition patterns were similar for both exit shapes, bed changes were more pronounced for run 2 over the same simulation time and river discharge. The sharp corner induced strong inflows that increased sediment trapping in the cavity. Also, the reduced opening to the main channel concentrated erosion and deposition in a more limited area. The presence of a secondary gyre had no significant effect on bedload transport in the abandoned channel mouth.

\subsection{Field case: Observed erosion/deposition patterns}

The morphodynamical evolution of the Port-Galland side cavity can be evaluated from the topographic surveys performed throughout the 2005-2008 period (Fig. 6). Fig. 12 shows differences in interpolated bed topography between 2006 and 2005-a (a), 2008 and 2006 (b), and 2008 and 2005-a (c). The topographic maps established in 2005-b and 2007 were not considered here because the upstream corner of the cavity had not been properly characterized. Considering the uncertainties associated with the field measurement protocol and with the data interpolation, only elevation changes greater than $20 \mathrm{~cm}$ are considered significant. Areas where the interpolated bathymetry was not properly constrained by raw data points were discarded and blanked in Fig. 12. Overall, changes in bed morphology are consistent with the flow patterns provided by the observations and the conceptual model. The results also indicate that substantial amounts of erosion and deposition occurred within the mouth of the abandoned channel. While the inerodible downstream corner of the cavity showed no significant evolution, aggradation of the gravel deposit (cf. Section 3.1) at the downstream corner and erosion of channel bed at the usptream corner were pronounced.

The upstream corner of the cavity migrated approximately $4 \mathrm{~m}$ in 2005-2006, and only $\sim 1 \mathrm{~m}$ in 2006-2008. This bank retreat corresponds to bed degradation adjacent to the corner of more than $1 \mathrm{~m}$ (2 m locally). The gravel deposit aggraded by as much as $1 \mathrm{~m}$ and propagated inward into the cavity as much as $10 \mathrm{~m}$ in 2005-2006. In 2006-2008 much less deposition occurred (less than $60 \mathrm{~cm}$ vertically over $5 \mathrm{~m}$ horizontally). The partial information contained in survey 2005-b indicated that deposition (and certainly bank erosion) mainly occurred during the 2006 flood season (between surveys 2005b and 2006). However, minor erosion and inward propagation of the sand 


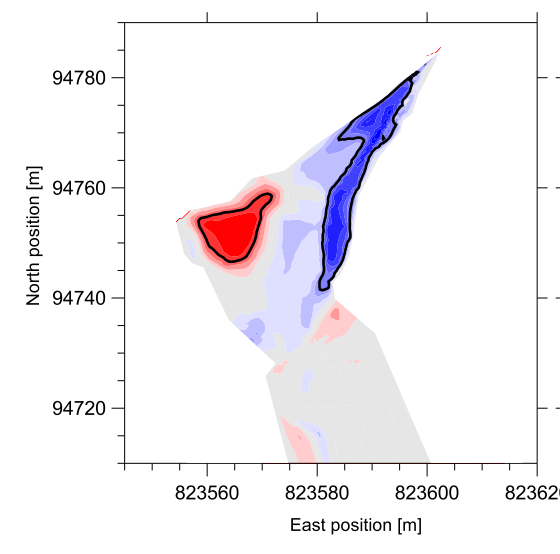

(a) 2005-2006

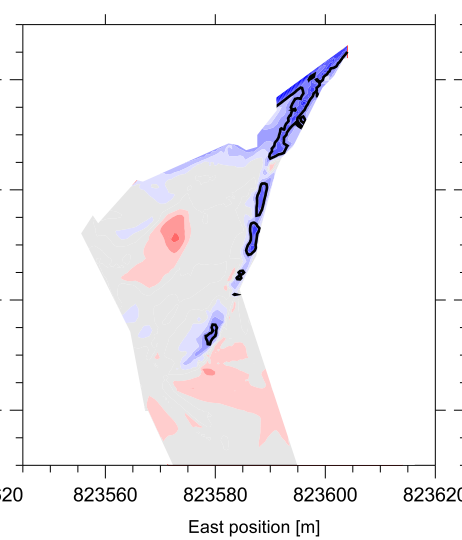

(b) 2006-2008

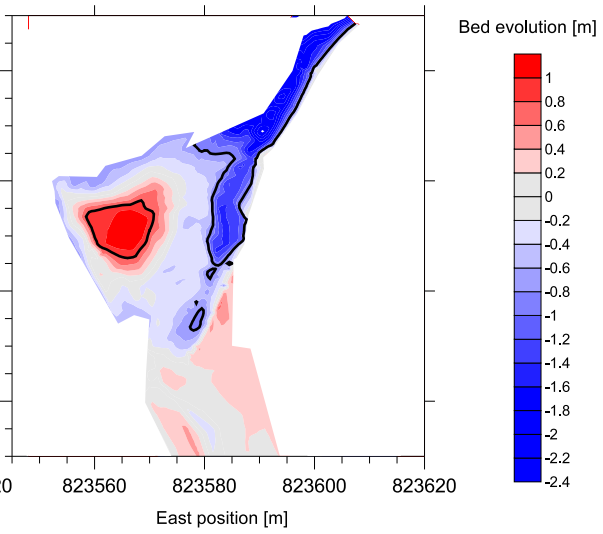

(c) $2005-2008$

Figure 12: Differences in interpolated bed topography over three periods. Changes greater than $80 \mathrm{~cm}$ (erosion or deposition) are highlighted by a black line.

bar which separates the mouth of the abandoned channel from the oxbow-lake were noticeable in 2006-2008.

\subsection{Field case: Fine sediment deposit layer}

The distributions of fine sediment deposits surveyed in 2005, 2006, 2007 and 2008 are presented in Fig. 13. The thick deposit $(>120 \mathrm{~cm})$ inward from the mouth of the cavity (around position 823580-94730) corresponded to a bar made of fine sand and silt, while deposits in the rest of the abandoned channel mainly consisted of silt. This silt layer, ranging in thickness from $60 \mathrm{~cm}$ to $1 \mathrm{~m}$, extended from the inward edge of the sand bar into the cut-off channel, over a distance of 40-50 m. Evident within the deposits is a small channel incised into the middle of the silt layer by groundwater driven flows during low discharge periods.

The sand deposit (not surveyed in 2006) appeared to be stable over the monitored 4-year period, whereas the silt layer showed more variability. Between the 2005 and 2006 campaigns, the silt layer regressed farther into the abandoned channel, but in 2006-2007 it propagated toward the mouth. In 2007-2008, the silt layer showed no significant evolution. 

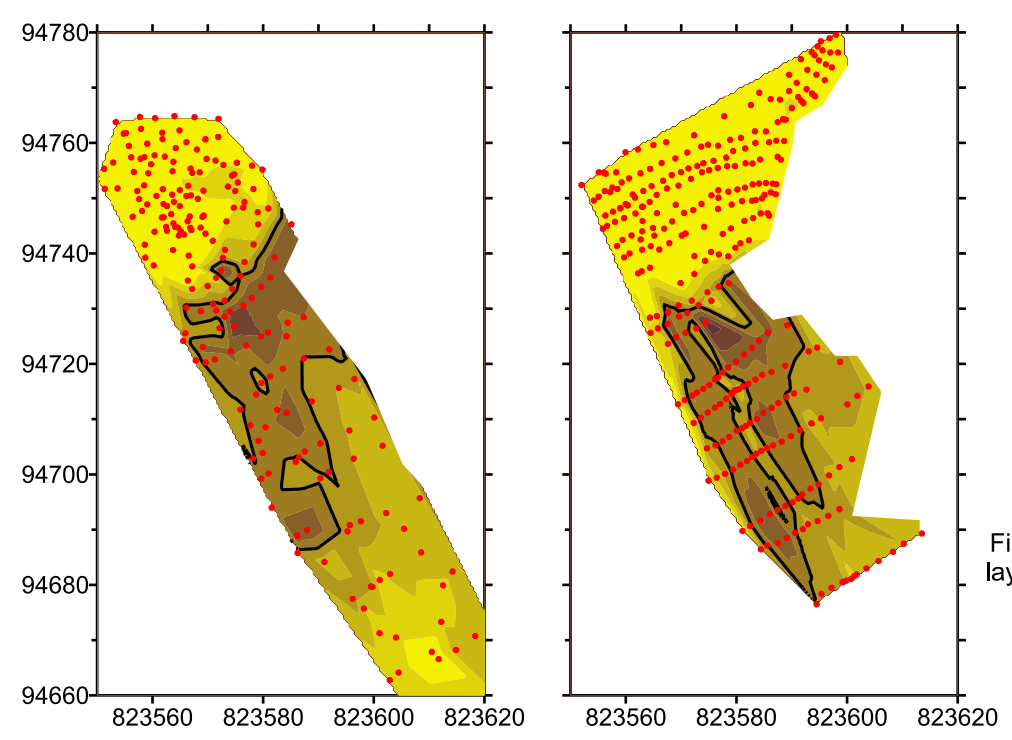

Fine sediment layer thickness
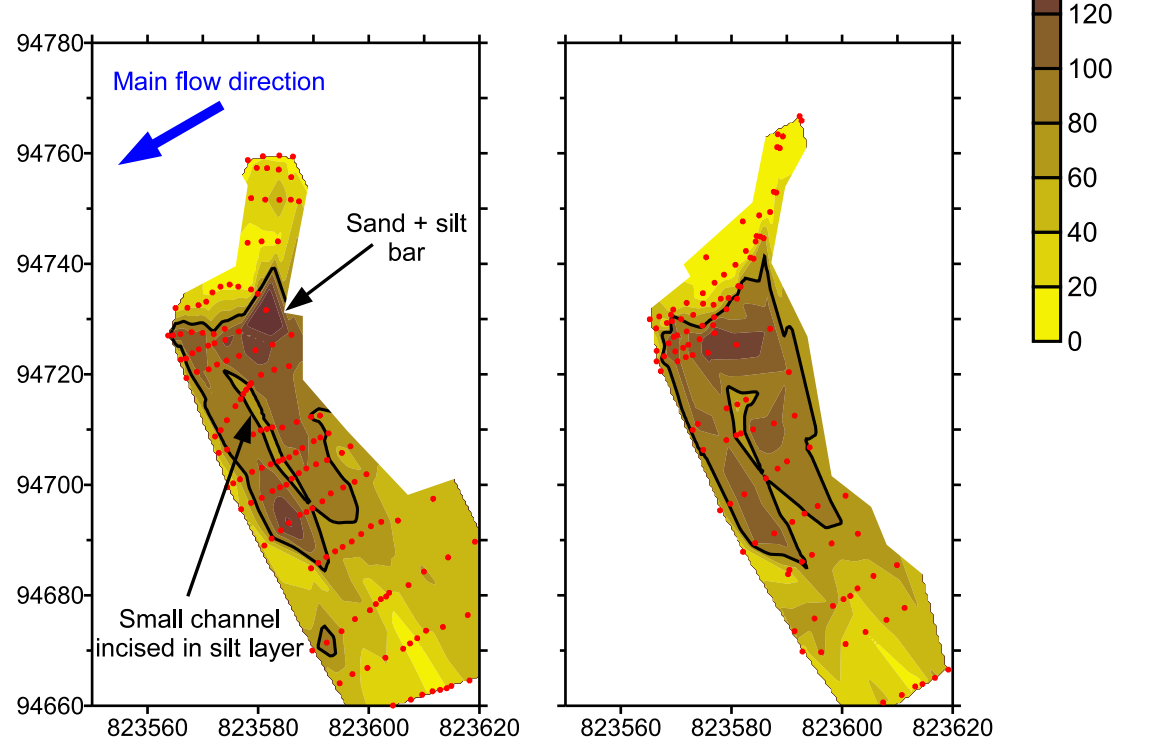

Figure 13: Maps of fine deposit layers: measured 7 June 2005 (top left), 6 September 2006 (top right), 6 November 2007 (bottom left), 24 July 2008 (bottom right) 


\section{Discussion}

\subsection{Consistency of local morphodynamical processes}

Important similarities were observed for the flow and morphodynamical patterns in both the laboratory and field investigations. The flow patterns organize around a main recirculation, with secondary gyres developing in the corners of the cavities elongated spanwise or streamwise. This is in agreement with the results from experimental and field studies on open-channel side cavities. The field case shows that the flow patterns change according to river discharge, mainly because the cavity geometry changed with the water level. The laboratory case illustrates the key role of the shape of the downstream corner (smooth/sharp) and of the contraction of the mouth of the cavity. Therefore, cavity geometry is the main factor that determines the flow patterns, much more so than the unsteadiness of the main flow. A simple analogy with flows in rectangular cavities may be used to characterize the flow patterns in more complex natural cavities. The experimental cavities were successfully decomposed into rectangular elements to define the corresponding recirculating systems likely to occur. This is of practical importance for engineering applications, even if determinations of the influence of cavity geometry on flow patterns may be more difficult when velocity observations are not available.

Observed morphological trends were also similar and were mainly governed by the main gyre, as opposed to the secondary ones. As is usually observed in field cases, open-channel cavities such as cut-off meander entrances and exits efficiently trap bedload. The bedload deposit is located in the vicinity of the downstream corner, although separated from it, and progrades inward into the cavity. More surprisingly, this deposition is accompanied by active scouring of the upstream corner of the cavity, which retreats when erodible. Practically, this implies that not only the downstream corner but also the upstream corner of the cavity should be protected if bank erosion must be avoided. It would be interesting to study experimental cases with an erodible downstream corner to assess whether it retreats from erosion by the incident flow.

The link between flow patterns and sediment transport appears to be quite complicated. The difference in nature between processes for suspended load and bedload must be taken into account. For instance, gravel deposits are not positioned in the center of the gyre, where velocity is lower, as 
can be observed for suspended load cases (Langendoen et al., 1994). Erosion and deposition areas appear to be associated with acceleration (outflow) and deceleration (inflow) trends, and also with 3D currents induced by the solid boundaries (Fig. 14). In contrast, sand and silt are deposited in the cavity wherever the velocity magnitude drops below the critical value for suspension.
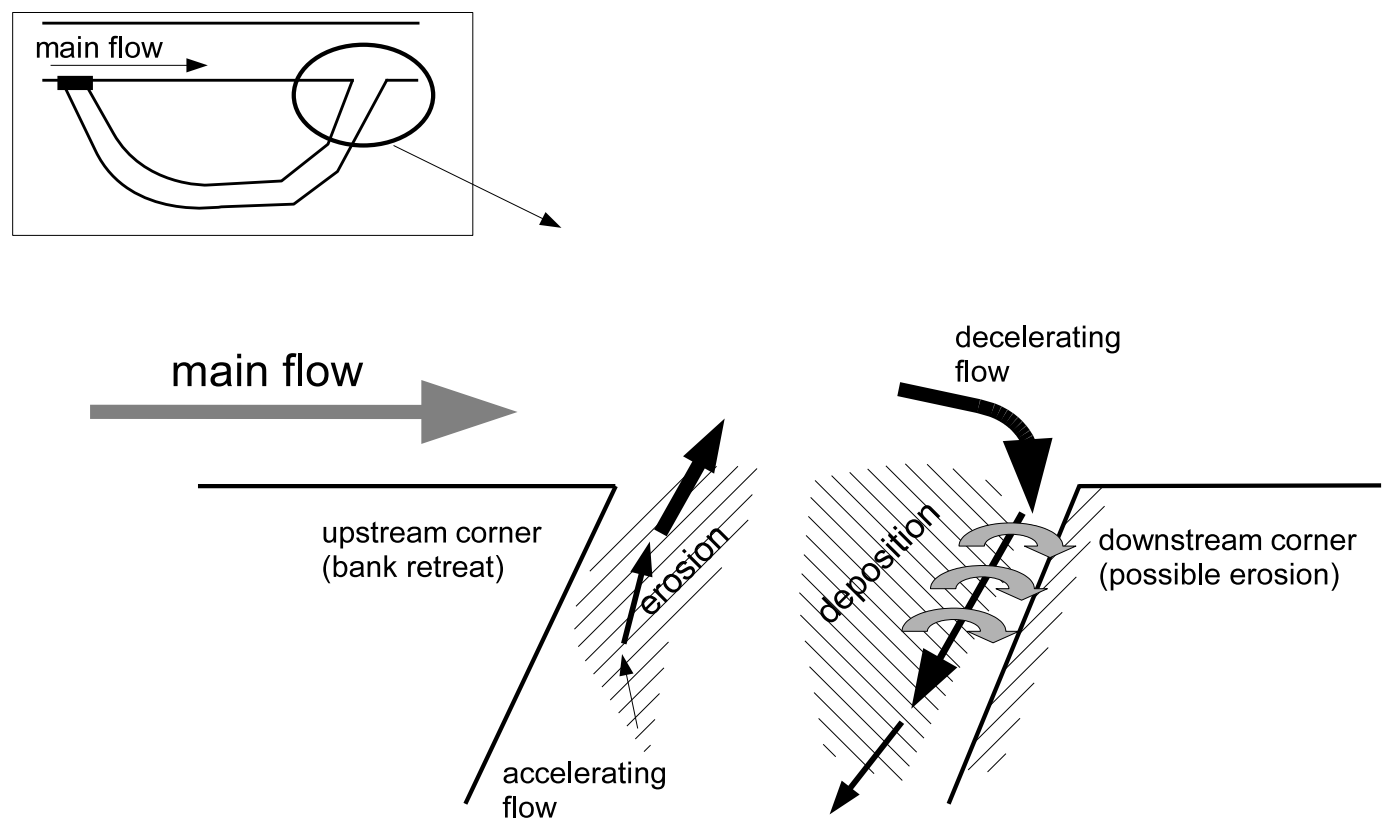

Figure 14: Conceptual sketch of bedload-related morphodynamical mechanisms in the exit of a cut-off meander.

\subsection{Effects of complex flow processes on sediment transport}

To assess the internal flow structure, each horizontal velocity measurement in a given vertical profile may be divided into a primary component $u_{1}$ and a secondary component $u_{2}$. There exists at least 4 possible definitions for establishing the secondary velocity field (Lane et al., 2000). The Rozovskii method (Rozovskii 1954, cited by Lane et al., 2000) consists of projecting velocities onto the direction of the depth-integrated velocity vector and the plane normal to this direction. Therefore, in a given vertical profile, depth-averaging of primary components yields the depth-averaged velocity, whereas depth-averaging of secondary components equals zero. The Rozovskii-based analysis is an appropriate way of identifying the presence of helical motion within a flow where the curvature of 
streamlines exhibits considerable spatial variability (Rhoads and Kenworthy, 1999).

Fig. 15 presents the average results of the Rozovskii decomposition of all the vertical velocity profiles measured by aDcp within the recirculating flows in the Port-Galland side cavity. The average profile of primary components over the flow depth deviates from the log profile typical of 2D uniform flows: over the upper half flow depth it decreases towards the free-surface (Fig. 15a). The average profile of secondary components (Fig. 15b) shows a centrifugal trend (negative values) over the upper half flow depth and a centripetal trend (positive values) over the lower half flow depth. The maximal magnitude of the centrifugal and centripetal secondary components equals $10 \%$ of $\langle u\rangle$, the local depth-averaged velocity. The order of magnitude of the vertical velocity component in the measured plunging and upwelling flows also equals $10 \%$ of $\langle u\rangle$. Fig. 15c shows that the direction of horizontal velocity ranges in \pm 5 degrees from the direction of the depth-averaged velocity vector.

This mean helical flow structure can also be directly detected in the velocity fields measured by aDcp, which offer a consistent view of secondary cells over several aDcp campaigns. Typically, plunging flows were observed against the downstream corner (embankment) and also against the upstream corner (eroded bank). Upwelling flows were observed in the vicinity of the gravel deposit. Three-dimensional flow structure was observed visually in the laboratory case, especially in the vicinity of the downstream corner of the cavity. By analogy with the case of groynes or meander bends, helical motion is induced by an imbalance between local inertial forces over the flow depth influenced by centrifugal acceleration and the counter-acting pressure gradient force associated with superelevation of the water surface (Engelund, 1974).

Beside complex 3D effects, intermittent effects probably play an important role in sediment transport in open-channel side cavities such as the exits of cut-off meanders. Quasi-periodic velocity fluctuations, synchronous with free-surface oscillations, were evident for rectangular flume cavity cases (Brevis et al., 2006; Kimura and Hosoda, 1997). Such intermittent effects were not measured in the laboratory case, but in the Port-Galland cavity velocity and free-surface oscillations were detected with similar periodicities of approximately $40 \mathrm{~s}$ (Le Coz, 2007). This intermittency of flow may have an influence on sediment transport in the cavity and may need to be taken into account in quantitative morphodynamical modelling. 


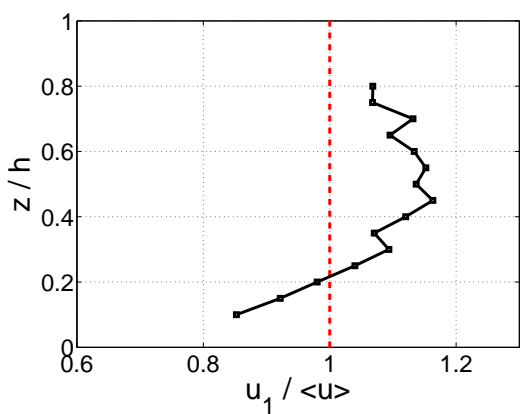

(a)

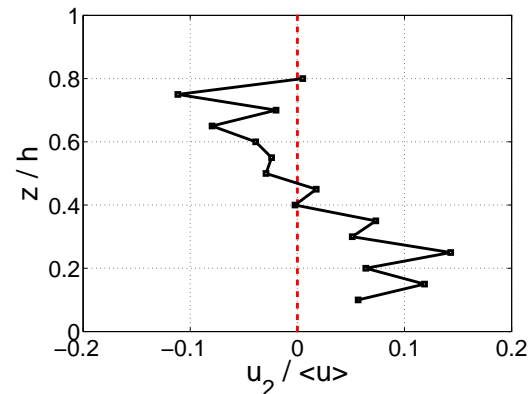

(b)

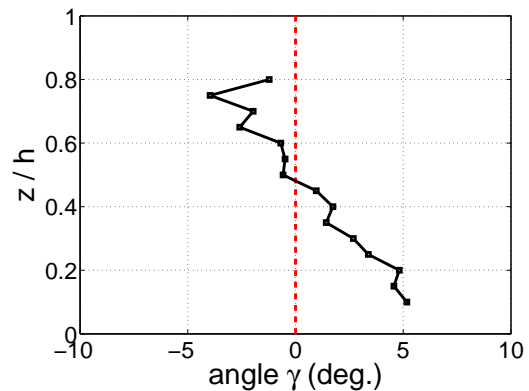

(c)

Figure 15: Average vertical profiles of the Rozovskii primary component, $u_{1}$ (a), of the secondary component, $u_{2}$ (b), and of the angle between the local velocity vector and the primary direction, $\gamma$ (c). The results of the Rozovskii decomposition of the velocity profiles from all the aDcp campaigns conducted within the Port-Galland cavity were averaged. Non-dimensional height above the bed ( $z$ divided by $h$, flow depth) is plotted against non-dimensional velocity (divided by $\langle u\rangle$, the local depth-averaged velocity), and the angle $\gamma$ (degrees).

\section{Conclusions}

The flow and sediment dynamics in the exit of a cut-off meander were investigated in two similar field and laboratory cases using innovative velocimetry techniques (acoustic Doppler profiling, image analysis). Both cases yielded consistent and complementary results from which a generic scheme for flow patterns and morphological evolution at the exit of cut-off meanders was derived.

In agreement with previous studies on open-channel side cavity flows, a main recirculating flow develops in the exit. According to the geometry of the cavity and to hydraulic conditions, counterrotating secondary gyres may also occur. In the laboratory case, a change in the shape of the downstream corner of the cavity induced a two-gyre system instead of a single recirculating flow patterns. In the field case, three regimes of complex flow patterns were distinguished according to the discharge in the main channel. In both cases, a simple analogy with flows in rectangular cavities was used to explain the observations.

As a consequence of the recirculating flow pattern, a decelerating inflow deposits bedload in the downstream part of the cavity, while the upstream part is eroded by an accelerating outflow, leading 
to the retreat of the upstream bank. Helicoidal secondary currents were observed, especially in the inflow, which may enhance the scouring of the downstream corner of the cavity. Fine sediment deposits constitute a silt layer in a transitional zone, located between the mouth of the abandoned channel and the oxbow-lake within the cut-off meander.

The degree to which the morphodynamical scheme can be generalized requires further confirmation through additional experimental, field and numerical studies of cut-off channel exits. The results presented here show that the geometry of the cavity mainly determines the local flow patterns, hence the morphological changes. A geomorphological analysis of cut-off channel exits, as well as systematic laboratory or numerical simulation, should particularly focus on the following geometrical controls: the angle of the abandoned channel with the main channel, the shape of the downstream corner (sharp/smooth), the contraction of the exit. In addition to geometrical controls, other factors should be taken into account for assessing the morphological adjustment of the exits of cut-off meanders, including the role of vegetation in stabilisation of deposits, the possible retreat of erodible banks, the effects of upstream connection events, and the morphological evolution of the river main channel (Piégay et al., 2000). From an ecological engineering point of view, the main practical goal of such studies is to find solutions for controlling the flow and deposition patterns at the entrances and exits of restored cut-off channels.

\section{Acknowledgements}

This work was supported by the Slovak Water Research Institute (VUVH), the French Embassy in Bratislava, the CNRS, and the Cemagref. Funding was provided by the following projects: project Modifications anthropiques des flux sédimentaires des cours d'eau 2003-2005 (Région RhôneAlpes), PNRH project 2003-2004 Fonctionnement hydro-sédimentaire d'annexes fluviales (French government), bilateral project Stefanik 2008-2009 on Sediment Transport and Fluvial Morphology (French and Slovak governments). We are grateful to the VUVH technical staff for their kind and useful help in the laboratory in Bratislava. The acquisition of flow and morphological data at Port-Galland would not have been possible without the help of many operators from the Cemagref, especially Céline Madigou, Fabien Thollet and Mickaël Lagouy. Earlier versions of the manuscript 
were significantly improved by Stephanie Moore and Benoit Camenen. Thoughtful and constructive comments from Prof. Bruce Rhoads and an anonymous reviewer were highly appreciated.

\section{References}

Amoros, C. and Bornette, G. (2002). Connectivity and biocomplexity in waterbodies of riverine floodplains. Freshwater Biology, 47(4):761-776.

Baptist, M. J. and Mosselman, E. (2002). Biogeomorphological modelling of secondary channels in the Waal river. In River Flow 2002, pages 773-782, Louvain-la-Neuve.

Brevis, W., Niño, Y., and Vargas, J. (2006). Experimental characterization and visualization of mass exchange process in dead zones in rivers. In River Flow 2006, pages 235-242, Lisbon, Portugal.

Citterio, A. and Piégay, H. (2008). Overbank sedimentation rates in former channel lakes: characterization and control factors. Sedimentology, 56(2):461-482.

Constantine, J., Dunne, T., Piégay, H., and Kondolf, M. (2009). Controls on the alluviation of oxbow lakes by bedload as observed along the Sacramento River of California. Sedimentology, in press.

Engelund, F. (1974). Flow and bed topography in channel bends. J. Hydraul. Div. Proc. ASCE, 100(HY11):1631-1648.

Fujita, I., Muste, M., and Kruger, A. (1998). Large-scale particle image velocimetry for flow analysis in hydraulic engineering applications. Journal of Hydraulic Research, 36(3):397-414.

Hauet, A., Kruger, A., Krajewski, W., Bradley, A., Muste, M., Creutin, J., and Wilson, M. (2008). Experimental system for real-time discharge estimation using an image-based method. Journal of Hydrologic Engineering, 13(2):105-110.

Holubova, K., Lukac, M., Sumbal, J., Kalis, J., Capekova, Z., Sporka, F., Tothova, L., and Cerny, J. (1999). Restoration of the Slovak Morava River meanders. Phare project, final report, Water Research Institute, Bratislava, Slovakia. 
Hooke, J. (1995). River channel adjustment to meander cutoffs on the River Bollin and River Dane, northwest England. Geomorphology, 14(3):235-253.

Kimura, I. and Hosoda, T. (1997). Fundamental properties of flows in open channel with dead zone. Journal of Hydraulic Engineering, 123(2):98-107.

Lane, S. N., Bradbrook, K. F., Richards, K. S., Biron, P. M., and Roy, A. G. (2000). Secondary circulation cells in river channel confluences: measurement artefacts or coherent flow structures? Hydrological Processes, 14:2047-2071.

Langendoen, E. J., Kranenburg, C., and Booij, R. (1994). Flow patterns and exchange of matter in tidal harbours. Journal of Hydraulic Research, 32(2):259-270.

Le Coz, J. (2007). Fonctionnement hydro-sédimentaire des bras morts de rivière alluviale (Hydrosedimentary processes in abandoned channels of alluvial rivers). PhD thesis, Ecole centrale de Lyon, France.

Le Coz, J., Pierrefeu, G., and Paquier, A. (2008). Evaluation of river discharges monitored by a fixed side-looking Doppler profiler (H-aDcp). Water Resources Research, 44(W00D09, doi:10.1029/2008WR006967).

Muto, Y., Imamoto, H., and Ishigaki, T. (2000). Velocity measurements in a straight open channel with a rectangular embayment. In 12th congress of APD-IAHR, page 353, Bangkok, Thailand.

Nezu, I. and Onitsuka, K. (2002). PIV measurements of side-cavity open-channel flows - Wando models in rivers. Journal of Visualization, 5(1):77-84.

Piégay, H., Bornette, G., Citterio, A., Hérouin, E., Moulin, B., and Statiotis, C. (2000). Channel instability as a control on silting dynamics and vegetation patterns within perifluvial aquatic zones. Hydrological Processes, 14:3011-3029.

Rhoads, B. and Kenworthy, S. (1999). On secondary circulation, helical motion and Rozovskiibased analysis of time-averaged 2D velocity fields at confluences. Earth Surface Processes and Landforms, 24:369-375. 
Rollet, A.-J. (2007). Etude et gestion de la dynamique sédimentaire d'un tronçon fluvial à l'aval d'un barrage: le cas de la basse vallée de l'Ain (Study and management of the sediment dynamics in a river reach downstream a dam: the case of the lower Ain river valley). PhD thesis, Université Jean Moulin Lyon III, France.

Rollet, A.-J., Piégay, H., Lejot, J., Citterio, A., and Dufour, S. (2005). Programme LIFE Nature - Conservation des habitats créés par la dynamique de la rivière d'Ain (LIFE Nature program Preservation of the habitats created by the Ain river dynamics). Technical report, UMR 5600, CNRS, Lyon, France.

Shields, F. and Abt, S. (1989). Sediment deposition in cutoff meander bends and implications for effective management. Regulated rivers : research and management, 4(4):381-396.

Simons, J., Barker, C., Schropp, M., Jans, L., Kok, F., and Grift, R. (2001). Man-made secondary channels along the river Rhine (the Netherlands); results of post-project monitoring. River Research and Applications, 17(4-5):473-491.

Sukhodolov, A., Engelhardt, C., Kruger, A., and Bungartz, H. (2004). Case study: turbulent flow and sediment distributions in a groyne field. Journal of Hydraulic Engineering, 130(1):1-9.

Sukhodolov, A., Uijttewaal, W. S. J., and Engelhardt, C. (2002). On the correspondence between morphological and hydrodynamical patterns of groyne fields. Earth Surface Processes and Landforms, 27:289-305.

Uijttewaal, W. S. J., Lehmann, D., and Van Mazijk, A. (2001). Exchange processes between a river and its groyne fields: model experiments. Journal of Hydraulic Engineering, 127(11):928-936.

Yokoyama, H., Watanabe, Y., and Suzuki, Y. (2004). Numerical simulation of bed change under compound channels flow in two-way main channel. In River Flow 2004, pages 1263-1271, Naples, Italy. 